\title{
Improving Human Development Index (HDI) by Illiteracy Eradication (Case Study in Cibadak Village)
}

\author{
Peningkatan Indeks Pengembangan Manusia (IPM) melalui \\ Pemberantasan Buta Aksara (Studi Kasus pada Desa Cibadak)
}

\author{
Indri Arrafi Juliannisa ${ }^{1)}$, Tri Siswantini ${ }^{2)}$ \\ ${ }^{1,2)}$ Fakultas Ekonomi dan Bisnis, Universitas Pembangunan Nasional Veteran, Jakarta \\ e-mail korespondensi: arrafi.juliannisa@gmail.com
}

\begin{tabular}{|l|}
\hline Article Info \\
\hline Article History: \\
Received: 06 November 2019 \\
Accepted: 13 December 2019 \\
Published: January 2020 \\
\hline DOI Number : \\
10.33059/jseb.v11i1.1784 \\
How to cite : \\
Juliannisa, I.A. \& Siswantini, \\
A. 2020. Improving Human \\
Development Index (HDI) by \\
Eradication Blind Letters \\
(Case Study in Cibadak \\
Village). Jurnal Samudra \\
Ekonomi dan Bisnis. \\
11(1): 29-42.
\end{tabular}

$11(1): 29-42$

\begin{abstract}
To measure the quality of human capital, The United Nations Development Program (UNDP) introduced the concept of human resource capital quality, named the Human Development Index (HDI). HDI is based on three dimensions i.e.: life expectancy at birth, literacy rate, mean years of schooling, and purchasing power parity. In this study raised the issue of the high illiteracy rate in Cibadak, Banten Province and the low expectation for old school. The situation will certainly be a barrier to the development process and economic growth through the human development index. The results showed that factors that could cause low educational status and illiteracy were grouped by researchers in research indicator variables, namely education, family, external environment, and information factors. The local government must pay more attention to this situation, because human resources are the driving wheel of the economy. The people really need care like reading and writing training assistance from the local government.
\end{abstract}

Abstract

Keywords: HDI, Illiteracy, Education.

\begin{tabular}{|l|l}
\hline Info Artikel & \multirow{2}{*}{ U } \\
\cline { 1 - 1 } Riwayat Artikel : & B \\
Diterima: 06 November 2019 & Disetujui: 13 Desember 2019 \\
Dipublikasikan: Januari 2020 & man \\
\hline
\end{tabular}

Nomor DOI :

10.33059/jseb.v11i1.1784

Cara Mensitasi :

Juliannisa, I.A. \& Siswantini, A. 2020. Improving Human Development Index (HDI) by Eradication Blind Letters (Case Study in Cibadak Village). Jurnal Samudra Ekonomi dan Bisnis. 11(1): 29-42.

\begin{abstract}
Untuk mengukur kualitas modal manusia, Program Pembangunan Perserikatan Bangsa-Bangsa (UNDP) memperkenalkan konsep kualitas modal sumber daya manusia, yang disebut Indeks Pembangunan Manusia (IPM). IPM didasarkan pada tiga dimensi yaitu: harapan hidup saat lahir, tingkat melek huruf, tahun sekolah rata-rata, dan paritas daya beli. Dalam penelitian ini mengangkat isu tingginya tingkat buta huruf di Cibadak, Provinsi Banten dan rendahnya harapan untuk sekolah tua. Situasi ini tentu akan menjadi penghambat proses pembangunan dan pertumbuhan ekonomi melalui indeks pembangunan manusia. Hasil penelitian menunjukkan bahwa faktor-faktor yang dapat menyebabkan status pendidikan rendah dan buta huruf dikelompokkan oleh peneliti dalam variabel indikator penelitian, yaitu pendidikan, keluarga, lingkungan eksternal, dan faktor informasi. Pemerintah daerah harus lebih memperhatikan situasi ini, karena sumber daya manusia adalah roda penggerak perekonomian. Masyarakat sangat membutuhkan perawatan seperti membaca dan menulis bantuan pelatihan dari pemerintah daerah.
\end{abstract}

Kata Kunci: IPM, Buta Aksara, Pendidikan. 


\section{INTRODUCTION}

Human Development Index (HDI) is a concept for measuring the quality of human capital, The high level of human development greatly determines the ability of the population to absorb and manage the sources of economic growth, both in relation to technology and to institutions as an important means of achieving economic growth. HDI is based on three dimensions i.e.: life expectancy at birth, literacy rate, mean years of schooling, and purchasing power parity (Lilya \& Sutrisna, 2014).

HDI is used to classify whether a country is included in the category of developed countries, developing countries or underdeveloped countries. This becomes a benchmark to find out the influence of economic policy in a country (Ningrum, 2017).

The Banten provincial government territory consists of 2 cities, 4 districts, 140 districts, 262 villages, and 1,242 villages. Banten sea area is one of the potential sea lanes, in addition Banten is a crossing/ connecting two major islands in Indonesia, namely Java and Sumatra. The population in Banten province until 2017 was 12.45 million people, with a workforce of 5.6 million people and 5.1 million people employed, in Banten Province the number of unemployed people was 499 people. Of course, the unemployment rate is still fairly high, and it is necessary to optimize employment absorption by Banten Province (BPS, 2018).

The Human Development Index (HDI) in Banten Province are a very decisive picture of the ability of the population to absorb and manage sources of economic growth, both in terms of knowledge, technology and institutions as an important means of achieving economic growth, while the HDI figures for 2017 in Banten province is showed in Table 1.
Table 1. Human Development Index (HDI) Banten Province in 2017

\begin{tabular}{lc}
\hline \multicolumn{1}{c}{ District / City } & $\mathbf{2 0 1 7}$ \\
\hline Pandeglang Regency & 63.82 \\
Lebak Regency & 62.95 \\
Tangerang Regency & 70.97 \\
Serang Regency & 65.6 \\
Tangerang City & 77.01 \\
Cilegon City & 72.29 \\
Serang City & 71.31 \\
Tangerang Selatan City & 80.84 \\
\hline \multicolumn{1}{c}{ Banten Province } & $\mathbf{7 1 . 4 2}$
\end{tabular}

Source: BPS, 2017.

Based on Table 1, it can be seen that Tangerang City is the city with the highest HDI and Lebak Regency is the district with the lowest HDI. The low HDI rate in Lebak Regency is caused by one factor, namely the high illiteracy rate. Lebak Regency is one of the regencies in Banten Province. Physiography of land in Lebak Regency is flat and ramps 90,033 Ha, undulating land and hilly land 104,792 Ha and mountainous/steep land 91,171 Ha (BPS, 2017).

In February, based on data from the Department of Education and Culture in the Regency of Lebak. around 2.5 percent or more than 30 thousand people of Lebak Regency are still illiterate. The high number of people who are illiterate in the Lebak Regency of Banten will certainly be a barrier to the development of the area, because illiterate people will be hampered in accessing important information, worsening the family's economy with the difficulty of finding work, and a decline in the level of social welfare (Alfarisi, 2016).

Based on Table 2 it can be seen that from 2014 to 2017 Lebak Regency did not achieve the school expectations set by the local government, of course this is due to one of them due to the large number of people who still hold illiterate status (BPS, 2017). 
Table 2. Expectations in School Length and Average Length of Schooling in Lebak Regency, Banten Province in 2017

\begin{tabular}{ccc}
\hline Year & School Expectation & Average Length of School \\
\hline 2014 & 11.88 & 5.84 \\
2015 & 11.90 & 5.86 \\
2016 & 11.91 & 6.19 \\
2017 & 11.92 & 6.20 \\
\hline
\end{tabular}

Source: BPS Lebak Regency, 2017.

One of the villages in Lebak Regency, which has low school expectations is the Cibadak Village. Based on Central Statistik in Cibadak Village, in 2017 there were 704 children who were supposed to have 6 years of compulsory elementary school, but only 389 people with primary school status, so there were still 315 people who did not attend primary school which resulted in their bearing status illiterate (BPS, 2017).

The situation will certainly be a barrier to the development process and economic growth through the human development index in Cibadak Village. The government must conduct other additional programs that can encourage the enthusiasm of parents and children to go to school, because having a good educational status will facilitate them in terms of the economy and social status in society. High and low illiteracy rates will be the main determinant of the quality of human development, because illiteracy rates account for two-thirds in the determination of the Human Development Index (HDI), one-third of the quality of education, and others are determined by health and welfare conditions. If this illiteracy is increasingly left unchecked, it will have an impact on the development of health, education and employment rates (Anwar, 2017; Zhang \& Kanbur, 2005).

\section{Human Development Index}

The important role of human capital is also explained in Human Capital Theory. Human Capital Theory assumes that educa- tion can improve the quality and income of a worker in the future. A person's decision to continue their education to a higher level is a form of investment as well as an opportunity cost (the best choice) with the hope that the person can obtain higher welfare in return for his education (Anwar, 2017).

The success of human development can be judged by how much problems can be overcome even more so the most problems fundamental. The existing problems include poverty, unemployment, incomplete education and the problem of the success of human development from other economic aspects. The achievement of development goals reflected in the human development index depends very much on the government as a provider of supporting facilities. HDI tries to rank all countries from a scale of 0 (the lowest level of human development) to 1 (level of human development the highest) based on three objectives or final products. The final product of development is first, longevity as measured by life expectancy. Secondly, knowledge is measured by weighted adult literacy (two-thirds) and average years of schooling (one third). Third is the standard of living (standard of living) as measured by real income per capita adjusted to the purchasing power parity (Marisca, 2016).

In UNDP (United Nations Development Program), human development is a process of charging people's choices. The concept or definition of human development mentioned above essentially covers a very broad 
dimension of development. In the concept of human development, development should be analyzed and understood from its human standpoint, not just from its economic growth. Based on this concept, the population is placed as the final destination while the development effort is seen as a means to achieve that goal (Ulumiyah et al., 2016). To guarantee the achieve-ment of human development goals, there are four main things which need attention, that is: (1) Productivity; (2) Equal distribution; (3) Continuity; and, (4) Empowerment (Fretes, 2017)

\section{Previous Research}

Anwar (2017) aims to provide empirical evidence of the central role of human capital on economic growth. This contribution is focused on Java because it is the center of economic activity in Indonesia, so it is necessary to analyze the contribution of human capital development to regional economic growth. This method uses panel data in 114 regencies and cities in Java during the period 2004-2013. Indicators of human capital used in this study are the average length of school for education and life expectancy for health. Estimation results show that education and health have positive contribution to regional economic growth. This indicates the important role of education as one of the main sources for achieving better economic development. Other findings from this research are the positive role of investment and the likely negative contribution of fiscal decentralization.

Jessica, et al. (2017) conducting research on the effect of HDI composite indicators on Lampung Province economic growth. This study aims to analyze the effect of the composite indicators of human development index (life expectancy, average length of schooling, literacy rate, and purchasing power) on the economic growth of
Lampung Province. The data used are time series data for the period 1999-2013 sourced from the Central Statistics Agency of Lampung Province. The model used in this study uses multiple linear regression using natural logarithmic form functions with Ordinary Least Square (OLS) estimation techniques. Estimation results show that life expectancy, average length of schooling, literacy rates, and purchasing power have a positive and statistically significant effect on economic growth. Suggestions from this study are for life expectancy variables, especially by reducing the high morbidity rate, for the average length of school variables and literacy rates, namely by increasing education, and for purchasing power variables, one of which is by maintaining a stable level of inflation.

Farah and Sari (2014) studied human capital which is regarded as one of the determining factors of productivity. Human capital is qualitative dimension of human resource that includes skills and knowledge. These qualitative dimensions are internalized through education, training and health. This study aimed to analyze the effect of human capital on productivity level across provinces in Indonesia. In this study, the level of education was measured by literacy and school enrollment rate (in primary, secondary and high school). The level of health was measured by infant mortality rate. The study employed a panel data of 25 provinces in Indonesia during the period of 1996-2010. Using fixed effect method, the result showed that secondary school enrollment rate and infant mortality rate are significant to explain the variation of productivity, albeit in smaller magnitude comparing to physical capital. The result also showed that the magnitude of education variable is higher than that of health variable. 


\section{METHOD}

This study uses quantitative and qualitative analysis techniques (mix methods) that focus on field and community conditions which suitable for the study area, namely Cibadak Village. Quantitative research techniques are methods that emphasize aspects of measurement objectively of social phenomena. Qualitative analysis technique is a method that emphasizes the aspect of in-depth understanding of a problem rather than looking at the problem for generalization.

This research method prefers to use indepth analysis techniques, which is to examine cases in a case case because the qualitative methodology believes that the nature of one problem will be different from the nature of other problems. The purpose of this methodology is not a generalization but an in-depth understanding of a problem (Sugiyono, 2015).
The number of respondents in this study were 155 , and a statistical test was conducted to find out the factors that could cause illiteracy in Cibadak Village, such as normality and validity tests. Other than that a SWOT (Strengths, Weaknesses, Opportunities, and Threats) analysis is performed to systematically identify various factors to formulate an organization/company strategy.

This analysis can clearly illustrate how external opportunities and threats faced by the organization/company can be adjusted to their strengths and weaknesses. The purpose of the SWOT analysis is to find out strategies in the framework of efforts to deal with the problem of illiteracy, while the data used are primary data derived from documentation, interviews, and questionnaires, as well as secondary data from Observation and literature studies. The research variable indicators used are showed in Table 3.

Table 3. Operationalization of Research Variables

\begin{tabular}{|c|c|c|c|}
\hline Object & Variables & $\begin{array}{l}\text { Dimensions and/or } \\
\text { Indicators }\end{array}$ & $\begin{array}{c}\text { Scale of } \\
\text { Measurement }\end{array}$ \\
\hline \multirow[t]{4}{*}{$\begin{array}{l}\text { Identify factors that } \\
\text { can cause high } \\
\text { illiteracy rates }\end{array}$} & Education & $\begin{aligned}> & \text { Education costs } \\
> & \text { Quality of Education } \\
> & \text { Formal and informal } \\
& \text { education } \\
> & \text { Distance between } \\
& \text { residence and place of } \\
& \text { study }\end{aligned}$ & $\begin{array}{l}\text { Nominal dan } \\
\text { ordinal }\end{array}$ \\
\hline & Family & $\begin{array}{l}\text { Inability of economic } \\
\text { conditions }\end{array}$ & Nominal \\
\hline & $\begin{array}{l}\text { External } \\
\text { environment }\end{array}$ & $\begin{array}{l}>\text { Not from an educated place } \\
\text { The environment is weak } \\
\text { economy }\end{array}$ & Nominal \\
\hline & Information & $\begin{array}{l}>\text { Clarity of Information } \\
>\text { Information sources } \\
>\text { Access information }\end{array}$ & Nominal \\
\hline
\end{tabular}




\section{RESULTS}

\section{Village Overview}

Cibadak Village is not a coastal area but a low-lying area outside the forestry area. The population of Cibadak village until 2017 is 4950 people, with a population density of 2475 people / $\mathrm{km} 2$. The number of residents who work as farmers is 595 , as farm workers is 532 people, as a fishermen is 4 , as a civil servants is 18 , as a home industries is 5, 402 people trade and as other services as many as 245 people. In this village there is also one citizen who is an Indonesian Worker (TKI) in the country of Saudi Arabia (Sugianto et al., 2018).

\section{Potential of Cibadak Village}

In this village there are educational facilities such as 1 Public Elementary School, 1 Private Elementary School, Early Childhood Education and 2 Sanawiyah. Most of the residents' last education is junior high school. The cultural arts found in this village are marawis and pencak silat.

In this village there are no domestic companies or foreign companies established, there are only entrepreneurs such as; ginger workshop and laber. In 2018 there are 1638 families, the infrastructure of the Cibadak Village is now well paved, the water supply in this village is quite adequate, but during the dry season the village is also experiencing water shortages, due to remote water sources. In Cibadak Village there is no public transportation, so residents must have a private vehicle or rely on a base motorcycle taxi.

In the economic field there are four groups of farmers and counselors in the form of; paddy and secondary crops, but during the dry season the farmers cannot work, because it is far from irrigation so there is no irrigation. For environmental sanitation, garbage disposal has not received assistance from the local sanitation department, so they still use manual methods to dispose of garbage by burning, and there is no specific garbage disposal site.

The leading economic sector in this village is the agricultural sector, with a total production of 812.2 per ton/year. Fruits which have potential as fertile plants in this village such as; mango with a production of $80 \mathrm{Kw} /$ year, rambutan $450 \mathrm{Kw} /$ year, duku $7 \mathrm{Kw} /$ year, durian $150 \mathrm{Kw} /$ year, guava $200 \mathrm{Kw} /$ year, papaya $6 \mathrm{Kw} / \mathrm{year}$, banana $350 \mathrm{Kw} /$ year, pineapple $5 \mathrm{Kw} /$ year, nangka $80 \mathrm{Kw} /$ year, water guava $40 \mathrm{Kw} /$ year, breadfruit 7 $\mathrm{Kw} / \mathrm{year}$, and melinjo $350 \mathrm{Kw} / \mathrm{year}$. This village is included as the village that ranks 2nd as the producer of manga fruit in Cibadak sub-district in 2017. Processing of agricultural land already uses a tractor, and in this village often gets subsidies for fertilizer for agricultural crops.

There are types of home industry businesses in this village such as; 25 wood craft groups, 5 weaving craft groups, 4 food craft groups and 8 brick lio craft groups. In this village there is no permanent market, minimarket, banking, and cellular tower. In this village, it has the potential to become a village of ginger plant development, but the potential for tourism area is not found (Sugianto, et al., 2018).

\section{The State of the Education and Illiteracy Sector in Cibadak Village}

Based on Central Statistics in Village in 2017 there were 704 children who were supposed to be compulsory for 6 years of elementary school, but of the total there were only 389 people with primary school status, so there were still 315 people who did not attend primary school and resulted in them bearing the status illiterate, 315 people with illiteracy consisted of ages 5-9 years as many as 105 people, aged 10-14 years as many as 87 people, age 45-49 years as many as 30 , 
ages 50-54 as many as 23 people, age 55-50 as many 18 people, age 60-64 as many as 26 people, age 65-69 as many as 11 people, age $70-74$ as many as 12 people, age $75+$ as many as 3 people.

From those numbers, ages 5-9 and 1014 years are very many, illiteracy is certainly a lot of factors that can cause it to occur, for the village of Cibadak these factors are grouped into operational research variables as below, and the data obtained from the results interview with village officials (Table 4).

\section{SWOT Analysis \\ Strengths}

This village has the potential to be promoted in the economic field with the help of a corporate village community, village facilities are adequate and the village head has the spirit to build a better village, besides that the village infrastructure to the school premises is also sufficient, so as to facilitate access to education.

\section{Weaknesses}

Local village officials are less able to change the population's mindset about the importance of education and being able to read and write, and the number of available schools is very minimal, so residents who live far from the school find it difficult to do so, besides that the government also does not make programs that care about the problem the illiterate.

\section{Opportunity}

Village officials must be able to empower village people who have been highly educated and do not have illiteracy, so that they can make citizens aware of the importance of education, and the amount of vacant land should be used to build schools with the help of the local district government.

\section{Threat}

The village will lack productive human resources at a young age, because with the lack of motivation to read and write / learn, it will result in the community trapped in their comfort zones, they only work as farmers.

\section{Statistical Test Results of Factors that can cause Illiteracy in Cibadak Village}

Based on Table 5 it can be seen that there are 58 male respondents and 97 female respondents, in this case the male respondents are far more than the female respondents. Based on Table 6, the respondents who have no education/do not attend school is 68 people, have the latest kindergarten education as many as 70 groups and 17 people do not complete Elementary School. This research focuses on respondents who have no education or those with low education.

Table 5. Characteristics of Respondents by Gender

\begin{tabular}{|c|c|}
\hline $\begin{array}{c}\text { Characteristics of } \\
\text { Respondents by Gender }\end{array}$ & Total \\
\hline Male & 58 \\
\hline Female & 97 \\
\hline Total & 155 \\
\hline
\end{tabular}

Source: Primary Data, 2019.

Table 6. Characteristics of Respondents according to Latest Education

\begin{tabular}{lr}
\hline $\begin{array}{c}\text { Characteristics of } \\
\text { Respondents according to } \\
\text { Latest Education }\end{array}$ & Total \\
\hline $\begin{array}{l}\text { No Educational Experience } \\
\text { Kindegarten }\end{array}$ & 68 \\
$\begin{array}{l}\text { Do not Finish Elementary } \\
\text { School }\end{array}$ & 70 \\
\hline \multicolumn{1}{c}{ Total } & 17 \\
\hline
\end{tabular}

Source: Primary Data, 2019. 
Table 4. Identification of Factors Causing Illiteracy

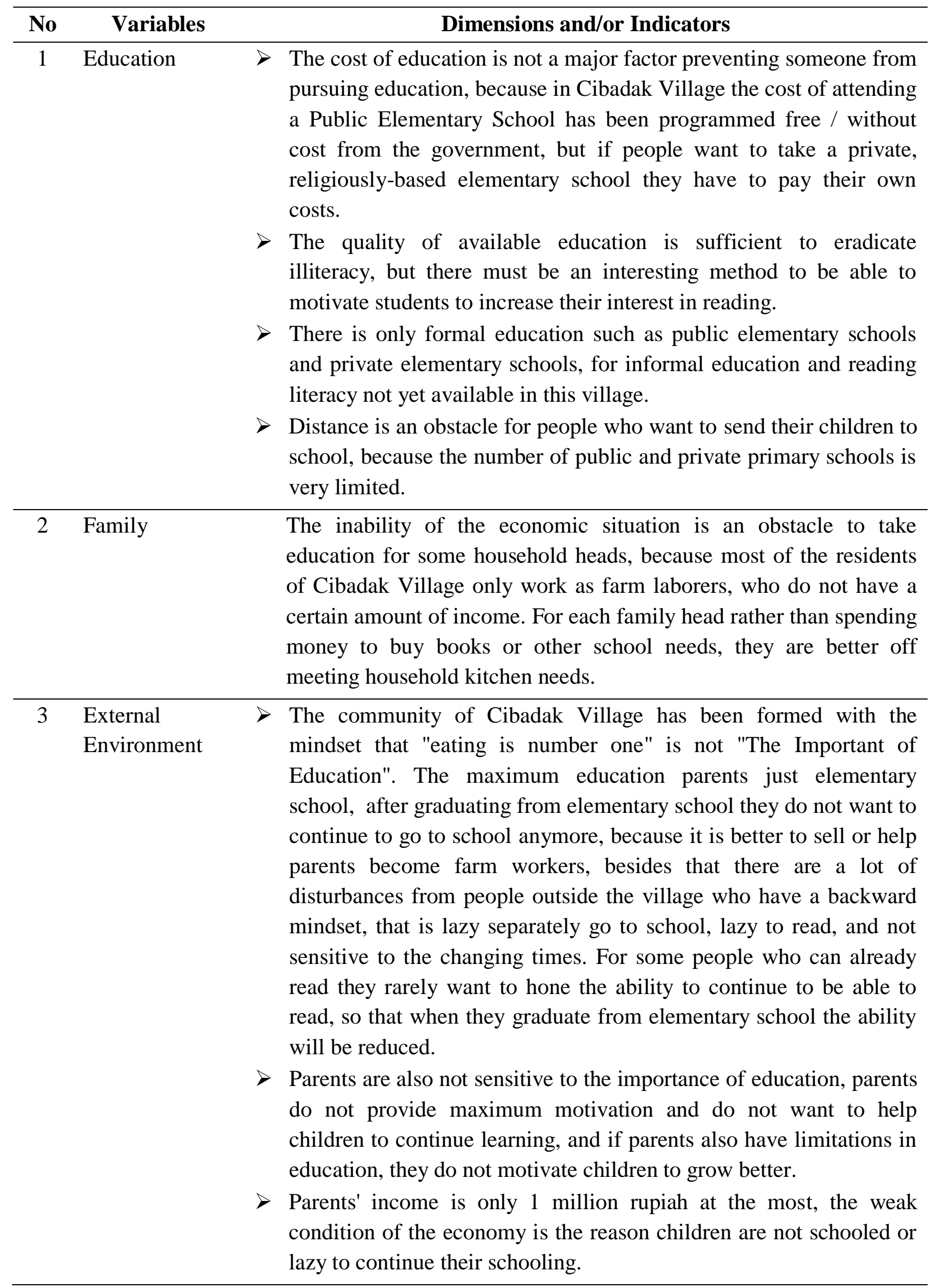




\section{Information $>$ Information about the education sector is very clear in this village,} but there is no more information from the local village government for illiteracy eradication programs or programs for poor families who want to continue their education.

$>$ The main source of information for the village is only from the village head's office.

$>$ Illiteracy is a fatal condition in the future, if villagers want to access more information for illiteracy eradication programs, they must be able to learn via the internet, but internet signal limitations are a barrier, and there are no volunteers from the government or private sector who want to help illiteracy alleviation program.

Source: Primary Data, 2019.

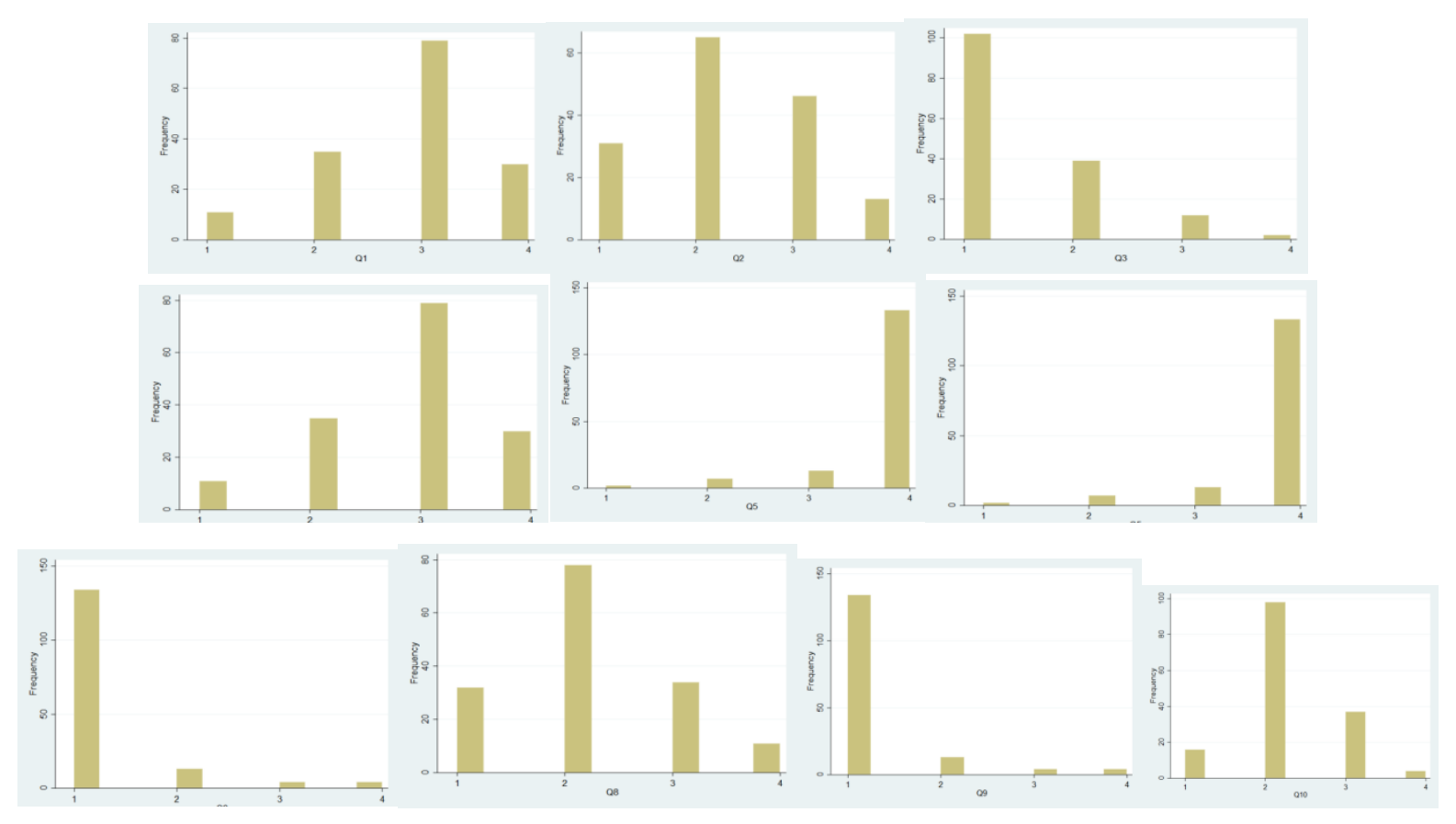

Figure 1. Histograms of Questionnaire

Source: Primary Data, 2019.

Questionnaire was used as the research instrument as a form of assessment of things that can cause a state of illiteracy/poor education of residents in the village of Cibadak. The question based on aspects; education, information, external environment, and family, with the following choice categories, i.e.: (1) Not suitable, (2) Not suitable, (3) Quite appropriate, and (4) Very suitable.
Based on Figure 1, it can be seen below for the first question or Q1 about the cost of education that becomes a problem in schooling, many respondents answered quite accordingly, which indicates that there are still some people who are having difficulty meeting the costs around educational needs. For the second question or Q2 about the satisfaction of the quality of education in terms of infrastructure, many respondents 
answered that it was not appropriate (unsatisfied), which indicates that the community felt the infrastructure available at the school was still inadequate or in accordance with current educational needs.

For the third question or Q3 about the availability of literacy training during the past 1 year, many respondents answered that it was not appropriate (none), which indicates that the village government apparatus was less sensitive to the illiteracy in the Cibadak village, there was no form of caring that can handle the problem. For the fourth question or Q4 about the problem of distance traveled to go to school, many respondents answered that it is quite problematic, that indicates that there are some people who feel that the distance from their home to school is quite far and it is an obstacle in taking education, thus causing they scream illiterate.

For the fifth question or Q5 about the background of the economic situation which is one of the causes of illiteracy, many respondents answered very well or agreed that indeed an inadequate economic background can be a trigger factor for someone to be reluctant to pursue education because of financial incapacity, so the problem of illiteracy in the family will continue.

For the sixth question or Q6 about the problem of illiteracy which is a factor that can cause a person to find work difficult so that the worsening condition of the household economy, many respondents answered very appropriate or they believe that if the illiteracy is not immediately handled properly by the apparatus village, it will have an impact on the village economy, because the economy of each household is not fulfilled as it should.

For the seventh or Q7 question about the origin of family education background, many respondents answered no, this indicates that illiteracy also originates from the origin of inadequate family education, if in one family does not have the enthusiasm or motivation to take higher education, it will have an impact on the generation of offspring in the family, because they modeled their parents first, the parents in this village have the view that it is enough to live by working as a farmer, and to work as a farmer does not need to have a high education or can be good at reading and writing.

For the eighth question or Q8 about the concern of the local government for people who are illiterate, many respondents answered that they did not care, this is because the community had not seen the form of handling the problem of illiteracy in this village. For the ninth question or Q9 about the assistance that the local government provides for those who are illiterate, many respondents answered none, this indicates that to date the local village government does not provide moral or material assistance to those families who are illiterate.

The last question or Q10 regarding agreement if a private party conducts illiteracy training in the village, many respondents answered disagree, this is because the community wants the assistance to come from the local government without the help of the private party, because if there is a private party who interferes they think will become private slaves, so that even the illiterate citizens hope that the nearest university will send students to conduct literacy training in this village.

Based on Table 7, it is known that the results of the normality test of 10 questions regarding the quality of service provided by the Bojongcae and Cibadak village government to the local community, there are six questions that are normally distributed and four questions that are not normally distributed, including questions number 2, 3, 5 and 9. These questions are categorized as 
normally distributed if the Prob. $>\mathrm{chi}^{2}$ value is greater than the trust standard of $5 \%$, and vice versa if the Prob> $\mathrm{chi}^{2}$ value is smaller than the trust standard of $5 \%$, it can be said that the question is not normally distributed. Questions 2, 3, 5, and 9 are not normally distributed because the number of vulnerable choices of answers that have been chosen by the respondents is not evenly distributed between choices 1 to 4 , in which the 1 st choice category is for the inappropriate category, the second choice is for the inappropriate category, option 3 is for the appropriate category and the last choice is 4 is the choice for the very appropriate category.
Part of the kurtosis value can be seen that it is greater than 0.263 , it can be categorized into leptokurtic distribution, which means that this distribution narrows at the top or near point. This situation shows that the frequency tends to accumulate in the area around the mean value or shows only a few frequencies that spread further than the central tendency value, and based on table 4.8 it is also known that for the plan 1 to 10 the skewness is in the range -1.96 and +1.96 , then the data is close to symmetrical (Ghozali, 2016).

\section{Table 7. Normality Test Results}

\begin{tabular}{|c|c|c|c|c|c|c|}
\hline \multirow[b]{2}{*}{ Variable } & \multicolumn{4}{|c|}{ Skewness/Kurtosis tests for Normality } & \multirow{2}{*}{$\overline{\operatorname{chi2}(2)}$} & \multirow{2}{*}{$\begin{array}{l}\text { int } \\
\text { Prob>chi2 }\end{array}$} \\
\hline & Obs & $\operatorname{Pr}($ Skewness $)$ & $\operatorname{Pr}($ Kurtosis) & $\operatorname{adj}$ & & \\
\hline q1 & 155 & 0.0246 & 0.7172 & & 5.16 & 0.0758 \\
\hline q2 & 155 & 0.2548 & 0.0230 & & 6.19 & 0.0454 \\
\hline q3 & 155 & 0.0000 & 0.0042 & & 33.63 & 0.0000 \\
\hline q4 & 155 & 0.0336 & 0.2679 & & 5.61 & 0.0605 \\
\hline q5 & 155 & 0.0000 & 0.0000 & & . & 0.0000 \\
\hline q6 & 155 & 0.0231 & 0.8448 & & 5.17 & 0.0753 \\
\hline q7 & 155 & 0.0353 & 0.3561 & & 5.24 & 0.0727 \\
\hline q8 & 155 & 0.0205 & 0.6726 & & 5.45 & 0.0654 \\
\hline q9 & 155 & 0.0000 & 0.0000 & & . & 0.0000 \\
\hline q10 & 155 & 0.0398 & 0.1691 & & 5.91 & 0.0520 \\
\hline
\end{tabular}

Source: Primary Data, 2019.

Validity test conducted by the research team used a Pearson correlation test or pairwise test. Can be seen below in var14 all questions, is that from Q1 to Q10 there is an asterisk $\left(^{*}\right)$, this indicates that all questions presented by the research team have been proven valid at the level of trust $1 \%, 5 \%$ and $10 \%$.

\section{Discussion}

Based on the results of statistical tests and the results of the SWOT analysis it can be seen that the Cibadak Village has potential in the economic field with the help of a corporate village community, village facilities are adequate and the village head has the spirit to build the village for the better. This village has adequate infrastructure so that it can make it easier to access education.

However, the village also still has weaknesses that can have an impact on decreasing the HDI. There are people who are still experiencing illiteracy problems caused by village officials who are less concerned with illiteracy issues and people who still have poor mindset and are less motivated in the world of education. Cibadak villagers think that there is no need for higher 
education because they only work as farmers and farm laborers. The influence of family backgrounds who do not have higher education becomes an influence in these families to not have high educational standards for their lives. Access to education is also inadequate, school distances are far and lack of public transportation facilities. Educational facilities in terms of facilities and infrastructure are still inadequate and do not motivate students.

Table 7. Validity Test Results

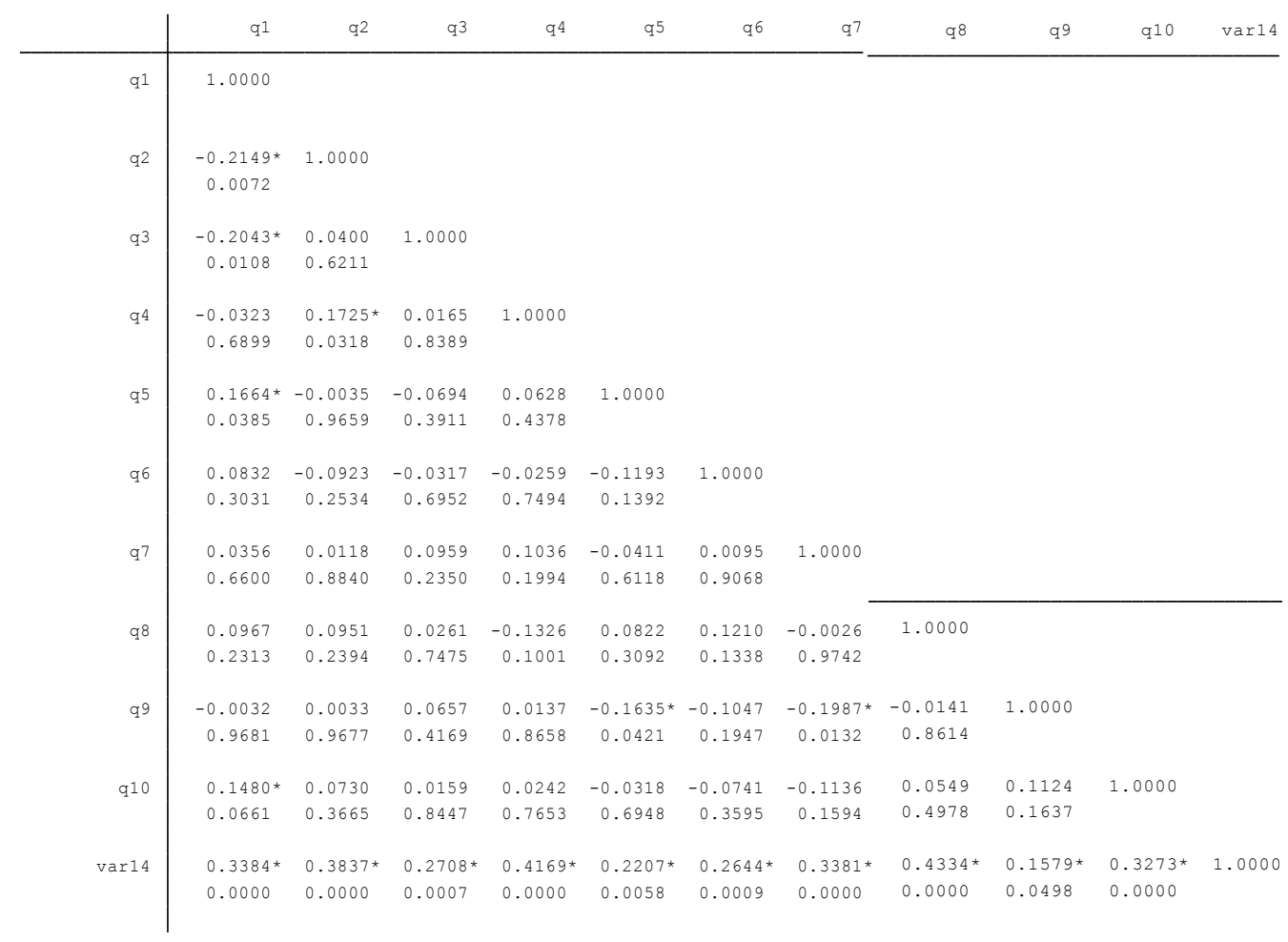

Source: Primary Data, 2019.

Until now the government has not provided training for those who have dropped out of school or are illiterate. This illiteracy situation is very influential for Cibadak village community, that is they are very difficult to get jobs with adequate income. The government should be more concerned about this problem by utilizing youth people or Karang Taruna Group to teach other people, and make programs using village funds and work with universities or private institutions to deal with this problem. If this problem continues to be ignored, then Cibadak village will lack productive human resources and so will have problems with village acceptance.

\section{CONCLUSION}

Bojongcae Village and Cibadak Village both have economic potential in the agricultural sector. Many residents have main jobs as farmers or farm laborers and the payment method accepted by farm workers is a profit sharing system.

The cost of education is not a major factor preventing someone from pursuing education, because in Cibadak Village the cost of attending a Public Elementary School has been programmed free or without cost from the government, but if people want to take a private, religiously-based elementary school they have to pay their own costs. 
The quality of available education is sufficient to eradicate illiteracy, but there must be an interesting method to be able to motivate students to increase their interest in reading. There is only formal education such as public and private primary schools, for informal education and reading literacy not yet available in this village.

Distance is an obstacle for people who want to send their children to school, because the number of public and private elementary schools is very limited, besides the economic factor of the family is also a problem for residents who suffer from illiteracy, for residents with illiteracy is far more important to make money than to spend money to meet the cost of education.

Parents' income is only 1 million rupiah at the most, this weak economic situation is the reason children are not schooled or lazy to continue their schooling. Communities are in dire need of care or reading and writing assistance from the local government, not from the private sector, so they can improve their future and economic situation.

\section{REFERENCES}

Alfarisi, A.S. 2016. Analisis Pendidikan Pedesaan dan Penyuluhannya di Desa Muaradua Kecamatan Cikulur, LebakBanten. Jurnal Aksioma Ad-Diniyah. 4(1): 103-126.

Anwar, A. 2017. Peran Modal Manusia terhadap Pertumbuhan Ekonomi Regional di Jawa. Jurnal Economica. 13(1): 79-94.

BPS. 2017. Ringkasan Ekslusif Perkembangan Ekonomi Provinsi Banten Triwulan III 2018. Banten: Badan Pusat Statistk.

BPS. 2018. Statistik Daerah Kabupaten Lebak 2018. Kabupaten Lebak: Badan Pusat Statistik.

Farah, A. \& Sari, E.P. 2014. Modal Manusia dan Produktifitas. JEJAK. 7(1): 22-28.
Fretes, P.N. 2017. Pengaruh Dana Perimbangan, Pendapatan Asli Daerah, dan Pertumbuhan Ekonomi terhadap Indeks Pembangunan Manusia di Kabupaten Kepulauan Yapen. Jurnal Akuntansi \& Ekonomi FE. UN PGRI Kediri. 2(2): 1-33.

Ghozali, I. 2016. Aplikasi Analisis Multivariat dengan Program IBM SPSS 23. Edisi 8. Semarang: Badan Penerbit Universitas Diponegoro.

Jessica, V., Halis, A., Ningsi, D.W., Virginia, G.F. \& Syahidah. 2017. Pemberantasan Buta Aksara untuk Peningkatan Kualitas Sumber Daya Manusia Masyarakat Sekitar Hutan Desa Manipi, Kecamatan Pana, Kabupaten Mamasa. Agrokreatif, Jurnal Ilmiah Pengabdian kepada Masyarakat. 3(2): 136-142.

Lilya, N.S. \& Sutrisna, I.K. 2014. Pengaruh Komponen Indeks Pembangunan Manusia terhadap Pertumbuhan Ekonomi Provinsi Bali. E-Jurnal Ekonomi Pembangunan. 3(3): 76-123.

Marisca, H. 2016. Pengaruh Kinerja Keuangan Daerah terhadap Indeks Pembangunan Manusia di Provinsi Jambi. Jurnal Prespektif Pembiayaan Dan Pembangunan Daerah. 1(1): 129140.

Ningrum, S.S. 2017. Analisis Pengaruh Tingkat Pengangguran Terbuka, IPM, dan Upah Minimum terhadap Jumlah Penduduk Miskin di Indonesia Tahun 2011-2015. Jurnal Ekonomi Pembangunan. 15(2): 184-192.

Sugianto, Permadhi, Y.T. \& Juliannisa, I.A. 2018. Perencanaan Pembangunan Daerah melalui Peran Partisipatif Pemerintah Desa Cibadak dan Desa Bojongcae, Kecamatan Cibadak, Kabupaten Lebak, Provinsi Banten. Proceedings. $4^{\text {th }}$ Annual International Conference on Economic in Developing Countries (AICEDC) "Economy for Sustainable Development", October $5^{\text {th }}$ $6^{\text {th }}$, FEB Universitas Jember. 
Sugiyono. 2015. Metode Penelitian Kombinasi (Mix Methods). Bandung: Alfabeta.

Ulumiyah, I., Gani, A.J. \& Mindarti, L.I. 2016. The Role of the Village Government in Empowering Village Communities. Department of Public Administration Universitas
Zhang, X. \& Kanbur, R. 2005. Spatial Inequality in Education and Health Care in China. China Economic Review. 16(2): 189-204.

Brawijaya. 1(5): 890-899. 